\title{
Bacteria simbion landscape (Oryctes rhinoceros L.) as a bioactivator for oil palm empty fruit bottle for organic mulsa
}

\author{
Marheni $^{1 *}$, Lahmuddin Lubis ${ }^{1}$ \\ ${ }^{1}$ Dosen Agroteknologi, Fakultas Pertanian, Universitas Sumatera Utara \\ *Email: marheni.sembiring@yahoo.com
}

\begin{abstract}
Oryctes rhinoceros is an important pest in oil palm plants attacking plants and immature plants. Utilization of oil palm empty fruit bunches in the field causes the spread and increase of O. rhinoceros attacks. The phenol compound and phenyl phenol released by decomposed oil palm empty fruit bunch attract O. rhinoceros to the organic material. The process of decomposition of oil palm empty fruit bunches 6-9 months resulted in an increase in pest population. O. rhinoceros larvae have symbiotic bacteria in their intestines and produce hydrolytic enzymes that have the potential and can be developed to degrade oil palm empty fruit bunch waste that is used as a composting starter. composting.

The materials used in this study were larvae of O. rhinoceros instar 3, culture media of NA, NB, fungi, trichoderma, yeast and other materials that support the research. Tools used in scalpels, measuring cups, microscopes and others.

The study was conducted at the Plant Disease Laboratory and Greenhouse, Agrotechnology Study Program, Faculty of Agriculture, University of North Sumatra, Medan from June 2019 to October 2019. This research used a Non Factorial Complete Randomized Design with 9 treatments and 3 replications. The results of the study were obtained 2 bacterial species namely Achromobacter SP and Bacillus SP then made as a composting activator. The use of this symbiont bacteria influences the physical and chemical factors of compost produced. As for physically obtained compost color in the treatment of P8 7.5 YR 2/1 (Black) while P0 7.5 YR 3/2 (Dark Brown). Compost has a soil aroma and temperature. Material reduction during composting from all treatments averaged $42.14 \%$. The best $\mathrm{C} / \mathrm{N}$ ratio is in the treatment of P7 (Bacillus + molasses) that is equal to $14.78 \%$ and the composting process lasts for 10 weeks.
\end{abstract}

Keyword: Symbiotic bacteria, Oryctes rhinoceros larvae, bioactivars, composting

\begin{abstract}
Abstrak
Oryctes rhinoceros merupakan hama penting pada tanaman kelapa sawit menyerang tanaman menghasikan dan tanaman belum menghasilkan. Pemanfaatan tandan kosong kelapa sawit di lapangan menyebabkan penyebaran dan peningkatan serangan O. rhinoceros. Senyawa fenol dan fenil fenol yang dikeluarkan tandan kosong sawit terdekomposisi memikat $\mathrm{O}$. rhinoceros mendatangi bahan organik tersebut. Proses dekomposisi tandan kosong kelapa sawit 6-9 bulan mengakibatkan terjadinya peningkatan populasi hama. Larva O. rhinoceros memiliki bakteri simbion di dalam ususnya dan menghasilkan enzim hidrolitik yang berpotensi dan dapat dikembangkan untuk mendegradasi limbah tandan kosong kelapa sawit yang dimanfaatkan sebagai stater pengomposan Tujuan dari penelitian ini yaitu pemanfaatan bakteri simbion larva O. rhinoceros L. sebagai activator untuk mempercepat proses pengomposan.

Adapun bahan yang digunakan dalam penelitian ini adalah, larva O. rhinoceros instar 3, media biakan NA, NB, jamur trichoderma, ragi dan bahan lain yang mendukung penelitian. Alat yang digunakan pisau bedah, gelas ukur, mikroskop dan lainnya.

Penelitian dilaksanakan di Laboratorium Penyakit Tumbuhan dan Rumah Kaca, Program Studi Agroteknologi, Fakultas Pertanian, Universitas Sumatera Utara, Medan dari Juni 2019 sampai Oktober 2019. Penelitian ini menggunakan Rancangan Acak Lengkap Non Faktorial dengan 9 perlakuan dan 3 ulangan. Adapun hasil penelitian didapat 2 sepesies bakteri yaitu Achromobacter SP dan Bacillus SP kemudian dijadikan sebagai activator pengomposan. Penggunaan bakteri simbion ini berpengaruh terhadap faktor fisik dan kimia kompos yang dihasilkan. Adapun secara fisik diperoleh Warna kompos pada perlakuan P8 7,5 YR 2/1 (Hitam) sedangkan P0 7,5 YR 3/2 (Coklat Tua). Kompos memiliki aroma dan suhu seperti tanah. Reduksi bahan pada
\end{abstract}


Marheni, dkk. Bacteria simbion landscape.

saat pengomposan dari seluruh perlakuan rata-rata sebesar $42,14 \%$. Ratio $\mathrm{C} / \mathrm{N}$ terbaik adalah pada perlakuan $\mathrm{P} 7$ (Bacillus + molase) yaitu sebesar 14,78\% dan proses pengomposan berlangsung selama 10 minggu.

\section{Kata Kunci: Bakteri simbion, larva Oryctes rhinoceros, bioaktivar, pengomposan}

\section{PENDAhULUAN}

Tandan kosong kelapa sawit belum optimal dapat dimanfaatkan sebagai sumber pupuk organic dikarenakan tumpukan mulsa tandan kosong kelapa sawit pada tanaman menghasilkan menyebabkan terjadinya kelimpahan populasi kumbang $\mathrm{O}$. rhinoceros dan larva dan pupa ditemukan sepanjang tahun di pertanaman kelapa sawit (Marheni, 2012).Yulia et al.(2010) mengatakan semakin tinggi tumpukan tandan kosong kelapa sawit semakin banyak populasi larva O. rhinoceros.

Tandan kosong kelapa sawit dan batang kelapa sawit merupakan media perkembangbiakan O.rhinoceros.Tandan kosong kelapa sawit mengandung 49,95\% selulosa, 22,85\% hemiselulosa dan 16,49\% lignin (Sidebang, 2008).

O.rhinoceros stadia larva mengkonsumsi tandan kosong kelapa sawit untuk pertumbuhan dan perkembangan larva menjadi pupa O.rhinocoeros. Kelangsungan hidup larva O. rhinoceros dengan pakan tandan kosong kelapa sawit berlangsung selama 102,46 hari sementara dengan pakan batang kelapa sawit mencapai 151,1 hari (Marheni, 2012).

Serangga memetabolisma pakannya terkait dengan akitifitas nutrisi dan hormon dalam pertumbuhan, metamorfosa dan reproduksi dilaksanakan oleh sel-sel dalam fat body. Fat body merupakan organ endokrin, perannya berhubungan dengan penyimpanan dan pemanfaatan nutrisi, menghasilkan beberapa antimikroba peptida dan berpartisipasi untuk detoksifikasi pada metabolisme nitrogen (Law and Well, 1989). Fat body disusun tiga sel diantaranya mycetocytes yaitu sel yang mengandung sejumlah mikroorganisma yang berada di dalam usus dan bersimbiosis dengan serangga. Mikroorganisme mensintesa berbagai nutrisi yang dibutuhkan serangga (Douglas, 1989)

Mikroba dalam usus serangga mampu menghasilkan enzim hidrolitik sehingga dapat memanfaatkan lignoselulosa sebagai sumber energi.(Suh et al. 2003). Bakteri memiliki berbagai aktivitas biokimia (pertumbuhan dan perbanyakan) dengan menggunakan raw material (nutrisi) yang diperoleh dari lingkungan sekitarnya. Transformasi biokimia dapat timbul didalam dan diluar dari bakteri yang diatur oleh katalis biologis yang dikenal sebagai enzim

Pelczar dan Chan (1988) mengemukakan bahwa bakteri asli saluran pencernaan mempunyai hubungan mutualisme dengan inangnya, yaitu memanfaatkan inang sebagai tempat hidupnya. Penelitian tandan kosong sawit sebagai media perkembangbiakan O. rhinoceros telah banyak diteliti namun penelitian ini bertujuan untuk mengetahui keberadaan bakteri simbion pada saluran pencernaan yang menyebabkan kemampuan tumbuh dan berkembang stadia larva menjadi pupa O. rhinocerosdengan pakan tandan kosong kelapa sawit.

Tandan kosong kelapa sawit yang dikompos secara alami memerlukan waktu cukup lama berkisar 6-9 bulan. Hal ini dipengaruhi oleh kandungan penyusunnya yaitu 45,9\% selulosa, 46,5\% hemiselulosa, dan 22,8\% lignin. Kandungan penyusun tandan kosong kelapa sawit sukar untuk terdekomposi (Susilawati, 2007).

Larva O. rhinoceros memiliki kandungan mikroba di dalam ususnya dan menghasilkan enzim hidrolitik. Potensi tersebut dikembangkan mendegrasi limbah tandan kosong kelapa sawit dengan cara mengisolasi dan memperbanyak bakteri didalam saluran percernaan larva dan dijadikan sebagai stater pengomposan tandan kosong kelapa sawit (Aini, 2015).

Bakteri simbion Larva O. rhinoceros termasuk dalam golongan bakteri thermofil dan dimanfaatkan sebagai stater pengomposan. Pemanfaatan stater bakteri dari genus Bacillus dapat mempercepat laju pengomposan dari 30 hari menjadi 18 hari (Sijabat et al., 2018). 


\section{METODE PELAKSANAAN}

Penelitian ini dilakasanakan pada bulan Juni 2019 hingga Oktober 2019. Eksplorasi bakteri dilakukan di Laboratorium Penyakit Tanaman Fakultas Pertanian Universitas Sumatera Utara dan pelaksanaan aplikasi stater pengomposan dilakukan di rumah kaca Fakultas Pertanian Universitas Sumatera Utara.

Bahan-bahan yang digunakan dalam penelitian ini adalah larva O. rhinoceros L instar 3 di ambil dari tandan kosong sawit yangdikumpulkan dari areal perkebunan kelapa sawit. MediaCMC (Carboxy methyl cellulosa),SCA (Simmon's Citrate Agar), TSIA (Triple Sugar Iron Agar), Media SIM, Gelatin, NB, bahan untuk uji pewarnaan gram (crystal violet, lugol iodine, safranin, etil alkohol 95\%, dan aquades), dan bahan lainnya yang diperlukan.Alat-alat yang digunakan untuk isolasi dan identifikasi antara lain, inkubator, autoclave, pipet, erlenmeyer,Bunsen, cawan Petri, neraca dengan ketelitian $0,1 \mathrm{~g}$, gelas ukur, kapas, mikroskop binokuler, gelas objek, jarum ose, Pisau bedah, Thermometer, Thermal block PCR, mesin elektroforesis, UV iluminator, laminar air flow, hot plate stirer, freezer, ember dan alat lainnya yang diperlukan.

Penelitian ini menggunakan Rancangan Acak Lengkap Non Faktorial dengan 9 perlakuan dan 3 ulangan, sehingga keseluruhan ada 27 perlakuan., P0 : Kontrol, P1 : Ragi $(60 \mathrm{ml})$, P2 : Molase $\quad(60 \mathrm{ml}), \mathrm{P} 3$ : A.xylosydans $(40 \mathrm{ml}), \mathrm{P} 4$ : A.xylosydans + ragi, P5 : A.xylosydans + molase, P6 : B.siamensis $(40 \mathrm{ml}), \mathrm{P} 7$ : B.siamensis + ragi, P8 : B.siamensis + molase.

\section{HASIL DAN PEMBAHASAN}

Hasil PCR divisualisasi pada gel agarosa $1 \%$ dan diwarnai dengan etidium bromida.DNA hasil amplifikasi tersebut dimurnikan lalu disekuens secara komersial untuk mengetahui urutan basa DNA-nya, Lalu data sekuens tersebut dibandingkan dengan data di GenBank dari database The National Center for Biotechnology Information (NCBI) (http://www.ncbi.nlm.nih.gov), menggunakan program Basic Local Alignment Search Tool (BLAST).

Identifikasi bakteri menggunakan 16S rRNA ini untuk mengetahui susunan dari nukleotida karena semua spesies memiliki perbedaan susunan atau deretan dari masing-masing rantai nucleotida (Timin, Guanin, Adenin, Citosin). Sehingga dari susunan nukleotida tersebut dapat dilihat atau diidentifikasi spesies atau nama suatu organisme.Hasil penelitian menunjukkan bahwa terdapat 2 (dua) isolat bakteri dan di identifikasi secara molekuler untuk analisis spesies menggunakan sekuensing 16S rDNA spesies bakteri yaitu Bacillus siamensis dan Achromobakter xylosoxidans.

B. siamensis adalah bakteri yang berasal dari gram positif, fakultatif anaerobik dan berbentuk batang dan bergerak. Koloni pada media berwarna putih krem. Tumbuh pada suhu $37 \mathrm{oC}$ dengan pH 6-7 (Sumpavapol et al., 2010).Menurut penelitian Chen et al (2016) B. siamensis merupakan bakteri biokontrol yang menghasilkan lipopeptida potensial mengurangi penggunaan pestisida dilahan pertanian untuk menghambat perkembangan jamur Fusarium oxysporum.

Achromobacter adalah bakteri yang merupakan gram-negatif bersifat aerob dan merupakan bakteri berbentuk batang tak berpigmen. Bakteri ini bersifat motil dengan satu atau lebih flagela. Bakteri dari genus Achromobacter ini tidak berkapsul, tidak membentuk spora, dan tumbuh dengan lambat. Bakteri genus Achromobacter dapat umum ditemukan di lingkungan yaitu pada tanah dan air, serta dapat pula ditemukan pada saluran pencernaan hewan seperti udang (Suminto, 2008).

Setelah didapatkan genus bakteri maka isolat bakteri tersebut dijadikan starter untuk mempercepat kematangan kompos. Karena genus Achromobacter dan Bacillus dapat menghasilkan enzim katalase dan oksidase yang dapat dimanfaatkan sebagai inokulum mikroba (Solihat, 2006). 
Marheni, dkk. Bacteria simbion landscape.

\subsection{Sifat Fisik Kompos}

\subsubsection{Suhu}

Berdasarkan hasil analisis sidik ragam dan dilanjut uji jarak duncan menunjukkan bahwa aplikasi bakteri dan bioktivator berpengaruh nyata terhadap suhu pengomposan.

Tabel 1. Pengaruh aplikasi bakteri dan bioaktivator terhadap suhu pengomposan 0-6 MSA $\left(0^{\circ} \mathrm{C}\right)$.

\begin{tabular}{llllllll}
\hline \multirow{2}{*}{ Perlakuan } & \multicolumn{7}{c}{ Perubahan Suhu } \\
\cline { 2 - 8 } & $0 \mathrm{msa}$ & $1 \mathrm{msa}$ & $2 \mathrm{msa}$ & $3 \mathrm{msa}$ & $4 \mathrm{msa}$ & $5 \mathrm{msa}$ & $6 \mathrm{msa}$ \\
\hline PO & $26,00 \mathrm{~b}$ & $27,17 \mathrm{e}$ & $27,67 \mathrm{e}$ & $30,83 \mathrm{~d}$ & $30,83 \mathrm{c}$ & $29,33 \mathrm{c}$ & $27,50 \mathrm{bc}$ \\
P1 & $26,33 \mathrm{ab}$ & $30,50 \mathrm{~cd}$ & $30,83 \mathrm{~d}$ & $31,17 \mathrm{~d}$ & $31,17 \mathrm{c}$ & $31,17 \mathrm{abc}$ & $27,50 \mathrm{abc}$ \\
P2 & $26,33 \mathrm{ab}$ & $30,00 \mathrm{~d}$ & $30,33 \mathrm{~d}$ & $31,00 \mathrm{~d}$ & $31,83 \mathrm{c}$ & $30,17 \mathrm{bc}$ & $28,50 \mathrm{ab}$ \\
P3 & $26,83 \mathrm{a}$ & $31,50 \mathrm{abc}$ & $34,83 \mathrm{c}$ & $37,50 \mathrm{c}$ & $36,00 \mathrm{~b}$ & $33,17 \mathrm{a}$ & $27,67 \mathrm{a}$ \\
P4 & $27,00 \mathrm{a}$ & $31,33 \mathrm{bc}$ & $36,83 \mathrm{~b}$ & $39,83 \mathrm{c}$ & $36,50 \mathrm{ab}$ & $33,00 \mathrm{a}$ & $27,67 \mathrm{abc}$ \\
P5 & $27,17 \mathrm{a}$ & $32,67 \mathrm{a}$ & $36,83 \mathrm{~b}$ & $43,00 \mathrm{~b}$ & $36,33 \mathrm{ab}$ & $33,00 \mathrm{a}$ & $27,50 \mathrm{a}$ \\
P6 & $27,17 \mathrm{a}$ & $31,50 \mathrm{abc}$ & $35,50 \mathrm{bc}$ & $44,83 \mathrm{ab}$ & $37,67 \mathrm{a}$ & $32,33 \mathrm{ab}$ & $27,83 \mathrm{c}$ \\
P7 & $27,00 \mathrm{a}$ & $31,83 \mathrm{ab}$ & $39,33 \mathrm{a}$ & $45,17 \mathrm{a}$ & $37,17 \mathrm{a}$ & $31,33 \mathrm{abc}$ & $28,33 \mathrm{a}$ \\
P8 & $27,17 \mathrm{a}$ & $32,33 \mathrm{ab}$ & $39,50 \mathrm{a}$ & $46,17 \mathrm{a}$ & $35,33 \mathrm{~b}$ & $31,83 \mathrm{abc}$ & $28,17 \mathrm{abc}$ \\
\hline
\end{tabular}

Keterangan : Angka yang diikuti huruf yang sama pada kolom yang sama tidak berbeda nyata menurut uji duncan pada taraf $5 \%$.

\subsubsection{Warna Kompos}

Perubahan warna kompos tergantung bahan campuran yang digunakan. Pengukuran warna bahan dilakukan menggunakan Munsell Soil Color Chart dengan sistem warna Munsell yang terdiri dari tiga dimensi independent yang dapat diibararatkan seperti silinder tiga dimensi sebagai warna tak teratur yang solid : hue, diukur dengan derajat sekitar lingkaran horizontal, chroma, diukur radial keluar dari netral (warna abu-abu) sumbu vertical, dan value, diukur vertical dari 0 (hitam) sampai 10 (putih). Munsell menentukan jarak warna sepanjang dimensi ini dengan mengambil pengukuran dari respon visual manusia (Valkatus, 2014).

Tabel 2.Pengaruh pemberian bakteri dan bioaktivator terhadap perubahan warna kompos.

\begin{tabular}{ll}
\cline { 2 - 2 } Perlakuan & Warna Kompos \\
\hline PO & 7,5 YR 3/2(Dark Brown) \\
P1 & 7,5 YR 3/2 (Dark Brown) \\
P2 & 7,5 YR 2,5/3(Very Dark Brown) \\
P3 & 7,5 YR 3/2 (Dark Brown) \\
P4 & 7,5 YR 3/2 (Dark Brown) \\
P5 & 7,5 YR 2,5/3(Very Dark Brown) \\
P6 & 7,5 YR 3/3 ( Dark Brown) \\
P7 & 7,5 YR 3/1 (Dark Brown) \\
P8 & 7,5 YR 2,5/1 (Black) \\
\hline
\end{tabular}

(Munsell Soil Color Chart) 
Hasil skoring warna menunjukkan pada awal pengamatan semua perlakuan menunjukkan hue yang sama (hue 7,5 YR), memiliki value yang sama dan chroma yang berbeda. Hal ini disebabkan adanya perbedaan pemberian bakteri simbion dan bioaktivator.

Perbedaan warna kompos pada akhir pengamatan menunjukkan tingkat kematangan kompos Junedi (2008) mengemukakan bahwa kompos yang dikatakan matang jika memiliki perubahan warna menjadi semakin gelap dan berbau tanah.

\subsubsection{Sifat kimia kompos}

\subsubsection{Kandungan C-org, $\mathbf{N}$ dan $\mathrm{C} / \mathrm{N}$ Kompos}

Analisis kandungan C-org, N dan C/N kompos dilakukan di PT. Socfin Indonesia. Kandungan Corg dan $\mathrm{N}$ pada kompos berhubungan dengan nilai $\mathrm{C} / \mathrm{N}$ kompos yang akan disajikan pada tabel berikut.

Tabel 3. Pengaruh pemberian bakteri dan bioaktivator terhadap kandungan $\mathrm{C}$-org, $\mathrm{N}$ dan $\mathrm{C} / \mathrm{N}$ kompos

\begin{tabular}{lllllll}
\hline \multirow{2}{*}{ Perlakuan } & \multicolumn{7}{c}{ Parameter } \\
\cline { 2 - 7 } & \multicolumn{1}{l}{ Kandungan C-Org $(\%)$} & \multicolumn{2}{l}{ Kandungan N $(\%)$} & \multicolumn{2}{l}{ Kandungan C/N } \\
\cline { 2 - 7 } & 8 MSA & 10 MSA & 8 MSA & 10 MSA & 8 MSA & 10 MSA \\
\hline PO & 42,16 & 35,88 & 1,61 & 2,05 & 26,19 & 17,5 \\
P1 & 43,72 & 36,97 & 1,64 & 2,08 & 26,66 & 17,77 \\
P2 & 41,85 & 37,91 & 1,87 & 1,7 & 22,38 & 22 \\
P3 & 42,32 & 36,66 & 1,47 & 1,73 & 28,79 & 21,19 \\
P4 & 42,63 & 36,03 & 1,65 & 1,9 & 25,84 & 18,96 \\
P5 & 41,38 & 37,13 & 1,53 & 1,74 & 27,05 & 21,34 \\
P6 & 42,94 & 36,35 & 1,61 & 1,94 & 26,67 & 18,74 \\
P7 & 40,75 & 37,6 & 1,88 & 2,67 & 21,68 & 14,78 \\
P8 & 42,32 & 39 & 1,83 & 1,74 & 23,13 & 22,41 \\
\hline
\end{tabular}

Hasil analisis kompos $\mathrm{C} / \mathrm{N}$ tertinggi pada minggu ke-8 diperoleh dari perlakuan $\mathrm{P} 3$ dan yang terendah P7 sedangkan pada minggu ke-10 hasil analisis $\mathrm{C} / \mathrm{N}$ tertinggi adalah $\mathrm{P} 8$ dan yang terendah P7. Menurut Atmojo (2003) penambahan aktivator, menyebabkan proses dekomposisi bahan organik berjalan cepat, sehingga terjadi penurunan kadar karbon. Kondisi tumpukan kompos dapat mengisolasi panas dengan cukup mengakibatkan kandungan $\mathrm{C}$ organik yang ada dalam setiap bahan kompos dapat terdekomposisi dengan baik.

Menurut Mirwan (2015) C-organik merupakan indikator telah terjadinya proses dekomposisi dalam pengomposan dan kematangan kompos. Kadar karbon cenderung mengalami penurunan. Dalam proses dekomposisi, karbon digunakan sebagai sumber energi untuk menyusun bahan selular sel-sel mikroba dengan membebaskan $\mathrm{CO} 2$ dan bahan lain yang menguap.

Kandungan C-organik pupuk berkisar dari tinggi sampai sangat tinggi. Total C-organik dalam pupuk dipengaruhi oleh kualitas bahan organik dan aktifitas mikroorganisme yang terlibat dalam penguraian bahan organik. Dalam proses dekomposisi, karbon digunakan sebagai sumber energi untuk menyusun bahan selular sel-sel mikroba dengan membebaskan $\mathrm{CO} 2$ dan bahan lain yang menguap. Penambahan aktivator, menyebabkan proses dekomposisi bahan organik berjalan cepat, sehingga terjadi penurunan kadar karbon. Kandungan karbon organik yang terdapat dalam kompos $\mathrm{P} 4$ dengan bioaktivator berupa ragi.

Menurut Sujiwo et al., (2012), peningkatan kadar N dikarenakan proses dekomposisi oleh mikroorganisme yang menghasilkan amonia dan nitrogen terperangkap di dalam tumpukan kompos karena pori-pori tumpukan kompos yang sangat kecil sehingga amonia dan nitrogen yang terlepas ke udara berada dalam jumlah yang sedikit. 
Tersedianya nitrogen dalam jumlah yang tinggi karena terjadi proses dekomposisi yang lebih sempurna, sedangkan nitrogen yang rendah disebakan kemungkinan nitrogen banyak menguap. Organisme yang bertugas dalam menghancurkan material organik membutuhkan Nitrogen $(\mathrm{N})$ dalam jumlah yang besar. Nitrogen akan bersatu dengan mikroba selama proses penghancuran material organik. Setelah proses pembusukan selesai, nitrogen akan dilepaskan kembali sebagai salah satu komponen yang terkandung dalam kompos.

Tandan kosong kelapa sawit mempunyai kadar C/N yang tinggi yaitu 45- 55 (Darmosarkoro dan Winarna, 2007). Hal ini dapat menurunkan ketersediaan unsur $\mathrm{N}$ pada tanah karena unsur $\mathrm{N}$ termobilisasi dalam proses perombakan bahan organik oleh mikroba tanah. Dari hasil pengomposan tandan kosong kelapa sawit pada berbagai perlakuan tersebut, jika dilihat dari imbangan $\mathrm{C} / \mathrm{N}$ rasionya menunjukkan bahwa sebagian besar kompos pada semua perlakuan telah sesuai dengan standar kualitas yang baik menurut SNI $19-7030$ - 2004 yaitu 10-20. Hanya pada perlakuan P2, P3, P5 dan P8 nilai ratio C/N masih cukup tinggi karena belum terurai secara keseluruhan.

\section{KESIMPULAN}

Perlakuan dengan warna yang paling pekat adalah G8 (Bacillus + molase) dimana hue (7,5 YR), value 2 dan chroma 1 (Black), sedangkan pada perlakuan P0 (kontrol) dimana hue (7,5 YR), value 3 dan chroma 2 (Dark Brown). Bau kompos yang paling cepat mengalami perubahan bau pada perlakuan G8 (Bacillus + molase) pada $2 \mathrm{msa}$, sedangkan pada perlakuan lain pada $3 \mathrm{msa}$. Ratio C/ N terbaik adalah pada perlakuan G7 (Bacillus + ragi) yaitu sebesar 14,78.

\section{UCAPAN TERIMAKASIH}

Tim pengabdian pada masyarakat mengucapkan terima kasih kepada pihak LPPM USU yang telah memberikan dana kepada pengabdian ini. Terima kasih juga kepada pihak mitra yang telah koopratif di dalam pelaksanaan pengabdian ini.

\section{DAFTAR PUSTAKA}

Aini N.A. 2015. Peranan Bakteri dalam Usus Rayap Tanah Macrotermes gilvus Hagen sebagai Agen Biologis Degradasi Bahan Organik. Skripsi, Jurusan Biologi FMIPA Universitas Negeri Semarang.

Antriana N. 2014. Isolasi Bakteri Asal Saluran Pencernaan Rayap Pekerja (Macrotermes spp.). Jurnal, Jurusan FMIPA Universitas Jember.

Arumsari S.A., Pangastuti., A. Susilowati., T. Purwoko dan D. Panutun. 2016. Celluloytic and Hemicellulotyic Bacteria from the gut of Oryctes rhinoceros Larva Biodiversitas. Vol 17 No 1.

Asngad A. dan Supardi.2005. Model pengembangan Pembuatan Pupuk Organik dengan Inokulum (Studi Kasus Sampah Di TPA Mojosongo Surakarta dalam Jurnal Penelitian Sains \& Teknologi, 6(20):101- 11 .

Bangun M.K. 1991. Rancangan Percobaan Bagian Biometri, Fakultas Pertanian, Medan.

Cappucino J.G. and N. Sherman. 1987. Microbiology, A Laboratory Manual. The Benjamin/Cummings Publishing Company Inc. California USA. P.127-148. 
Chandel M., Kaur S dan Kumar S. 2011. Studies on the genoprotective/antioxidant potential of methanol extract of Anthocephalus cadamba (Roxb) Miq. Journal of Medicinal Plants Research 5(19):4764-4770.

Chen Q., Liu W, Che, Liu G, Gong, Guan. 2016. Anti Fungal Lipopetides Produced by Bacillus Siamensis FJAT28592. Journal of Agricultural Biotechnology. DOI : 10.3969/J.ISSN. 16747968.

Darmoko dan A.S. Sutarta. 2006. Ilmu Tanah dan Agronomi. Dari http://TKS/ilmu_tanah_dan_agro nomi.htm. [diakses 20 Januari 2018].

Desi Y., Habazar T dan Khairul. 2014. Karakteristik morfologi dan fisiologis isolat-isolat Pantoea stewartii subsp. stewartii pada jagung. Jurnal Fitopatologi Indonesia 10 (2): 45-52. Esker.

Direktorat Jenderal Perkebunan. 2014. Statistik Perkebunan Indonesia Komoditas Sawit Tahun 2011-2013. Direktorat Jenderal Perkebunan, Kementerian Pertanian. Jakarta.

Elevri, P.A. dan S.R. Putra. 2006. Produksi Etanol Menggunakan Saccharomyces cerevisiae yang Diamobilisasi dengan Agar Batang. Akta Kimindo 1(2): 105 - 114

Elfiati D. dan E. B. Mulya. 2010. Pemanfaatan Kompos Tandan Kosong Sawit Sebagai Campuran Media Tumbuh Dan Pemberian Mikoriza Pada Bibit Mindi. Program Studi Kehutanan USU, Medan.

Hadioetomo R.S. 1990. Mikrobiologi dasar dalam praktek teknik dan prosedur dasar laboratorium. Penerbit PT Gramedia, Jakarta. Hal 103-104.

Hardi A. 2013 . Aplikasi Baculovirus oryctes Berkaitan dengan Ekologi Oryctes rhinoceros Pada Pengendaliannya di Perkebunan Kelapa Sawit. Instititut Pertanian Bogor.

Haryani A. 2012. Uji efektivitas daun pepaya (Carica papaya) untuk pengobatan infeksi Aeromonas hydrophila pada ikan mas koki (Carassius auratus). Skripsi. Program Studi Sarjana Perikanan. Universitas Padjadjaran.

Hidayat W. 2013. Isolasi dan Skrining Bakteri Selulotik Dari Saluran Percernaan Larva Oryctes rhinoceros. Skripsi, Jurusan Biologi FMIPA. Universitas Sebelas Maret.

Holt J.G., Krig, NR Sneath, P Staley, and Williams S.1994. Bergeys Manual of Determinative Bacteriology, 9th Edition, Lipincott William and Wilkins Company : Philadelphia USA.

Izza I. 2011. Isolasi Karakterisasi dan Identifikasi Bakteri Endofit dari Tanaman Mahkota Dewa (Phaleria macrocarpa) yang Berpotensi Sebagai Penghasil Antimikroba. FMIPA Universitas Islam Sunan Kalijaga. Yogyakarta.

James G., Cappuccino and Natalie Sherman. Published by Benjamin Cummings. 2014. Microbiology A Laboratory Manual is knon for its through coverage, 10th edition-my pearsonstore.

Jawetz E., Melnick J.L., and Adelberg. E.A. 2007. Mikrobiologi Kedokteran. Buku 1. Penerbit Salemba Medika. Jakarta. 
Khan, M.A.I., K. Ueno, S. Horimoto, F. Komai, K. Tanaka, Y. Ono. 2009. Physicochemical, including spectroscopic, and biological analyses during composting of green tea waste and rice bran. Biol Fertil Soils 45:305-313.

Kusmiyarti T.B. 2013. Kualitas Kompos dari Berbagai Kombinasi Bahan Baku Limbah Organik. Fakultas Pertanian Universitas Udayana. Bali.

Lay W.B. 1994. Analisa Mikroba di Laboratorium. Edisi I. Jakarta. PT.Raja Grafindo Persada.

Lestari D.S., Kamir R dan Rahayu. Pengaruh Trichoderma Sp. dan Molase Terhadap Sifat Biologi Tanah Di Sekitar Lubang Resapan Biopori Pada Latosol Darmaga. Departemen Ilmu Tanah dan Sumberdaya Lahan, Fakultas Pertanian IPB. Bogor.

Loring D.A. 2007. Competitive Testing of SLPLAT-RB (Oryctes rhinoceros ) Male Aggregation Peromone- Mass Trapping In Oil Palm And Coconout Estates. The Planter.(979): 657-663.

Marheni. 2012. Karakteristik Bioekologi Oryctes rhinocheros L. Pada Pertanaman Kelapa Sawit. Disertasi. UGM. Yogyakarta.

Miller J. C. 1991. Statistika untuk Kimia Analitik Edisi Kedua. Translated by Drs. Suroso, M.Sc. Bandung: Institut Teknologi Bandung.

Mohan. 2002. Deskripsi dan Ekologi Oryctes rhinoceros L. Pada Pertanaman Kelapa Sawit. Jurnal, Fakultas Pertanian Universitas Sebelas Maret.

Muyzer G, De Waal E, Uitterlinden G. 1992. Profiling of complex microbial populations by denaturing gradient gel electrophoresis analysis of polymerase chain reaction-amplified genes coding for 16s rRNA. 59(3): 695-700.

Sijabat O.S., Marheni dan Darma Bakti. 2018. The Identification Of Bacterial Symbiont's of The Larvae Oryctes rhinoceros L. and The Role of The Bacteria in Composting Process. Faculty of Agriculture University of North Sumatra. Medan. 